\title{
PEMBERIAN LATIHAN VIRTUAL REALITY LEBIH BAIK DARIPADA LATIHAN KONVENSIONAL TERHADAP PENINGKATAN FUNGSIONAL TANGAN PADA PASIEN PASCA STROKE
}

\author{
Muhammad Ruslan Nuryanto', DW.Pt.Gde Purwa Samatra², M.Irfan'3, \\ I Made Krisna Dinata ${ }^{4}$, Anak Agung Sagung Sawitri ${ }^{5}$, Sugijanto ${ }^{6}$ \\ ${ }^{1}$ Program Studi Magister Fisiologi Keolahragaan Universitas Udayana Denpasar Bali \\ ${ }^{2,4,5}$ Fakultas Kedokteran Universitas Udayana Denpasar Bali \\ ${ }^{3}$ Program Studi Fisioterapi Universitas 'Aisyiyah Yogyakarta \\ ${ }^{6}$ Fakultas Fisioterapi Universitas Esa Unggul Jakarta
}

\begin{abstract}
ABSTRAK
Latar belakang: Stroke merupakan gangguan neurologis pada otak yang menyebabkan terjadinya defisit neurologis salah satunya kelemahan ekstremitas yang mengakibatkan adanya keterbatasan fungsional anggota gerak atas yaitu tangan, oleh karena tonus abnormal sehingga otot menjadi tidak stabil. Tujuan: Penelitian ini bertujuan untuk mengetahui pemberian latihan Virtual reality lebih baik daripada latihan konvensional terhadap peningkatan fungsional tangan pada pasien pasca stroke. Metode: Penelitian ini bersifat studi eksperimental dengan menggunakan Randomized Control pre-post test design. Kelompok pertama berjumlah 6 sampel diberikan latihan Virtual reality menggunakan Sensor Leap Motion Controller selama 30 menit, sedangkan pada kelompok kedua berjumlah 6 sampel diberikan latihan konvensional selama 30 menit. Waktu penelitian dilakukan selama 4 minggu. Setiap sampel diajarkan dan diberikan bimbingan / instruksi agar mampu melakukan latihan dengan baik. Tes pengukuran fungsional tangan menggunakan instrumen Wolf Motor Function Test. Hasil: Hasil penelitian menunjukan pada kelompok pertama terjadi peningkatan kemampuan fungsional tangan sebesar $14,21 \%$ dan didapatkan nilai $\mathrm{p}=0,027$, dimana $\mathrm{p}<0,05$, untuk kelompok kedua terjadi peningkatan kemampuan fungsional tangan sebesar $8,47 \%$ dan didapatkan nilai $\mathrm{p}=0,001$, dimana $\mathrm{p}<0,025$, sedangkan perbedaaan peningkatan kemampuan fungsional tangan atas kedua kelompok menunjukan adanya perbedaan yang signifikan (nilai $\mathrm{p}=0,007$, dimana $\mathrm{p}<0,05$ ). Hal ini dapat disimpulkan bahwa latihan Virtual reality menggunakan Sensor Leap Motion Controller lebih baik daripada latihan konvensional terhadap peningkatan kemampuan fungsional tangan pada pasien pasca stroke.
\end{abstract}

Kata kunci: Stroke, Kemampuan fungsional tangan, Latihan Virtual reality, Latihan konvensional, Wolf Motor Function Test. 


\title{
VIRTUAL REALITY EXERCISE BETTER THAN CONVENTIONAL EXERCISE TO ENHANCEMENT OF FUNCTIONAL HAND FOR STROKE PATIENCE
}

\begin{abstract}
Background: Stroke is a problem of neurologist brain who causes occurrence of neurologist deficit such as a weakness of upper extremity. For instance, limited of hand functional and movement because of abnormality tonus that occur instability muscle. Methods: The purpose of this research was to knew effect of additional virtual reality exercise better than conventional exercise to enhancement of functional hand for Stroke patience. This research is experimental study which used a Randomize Control pre-post test design. The first category is 6 samples be given Virtual reality Exercise with Sensor Leap Motion Controller during 30 minutes. And the second category is 6 samples be given conventional exercise during 30 minutes. The times of research for 4 weeks under the supervision of Physiotherapist to do well. Measurement test of hand functional with used of Wolf Motor Function Test instrument. Results: The result of this research showed to the first category occur of ability improvement of hand in the amount of $14,21 \%$ and be obtained value $p=0,027$, which one $p<0,05$. The second category occur of ability improvement of hand in the amount of $8.47 \%$ and be obtained value $p=0,001$, which one $p<0,025$. Meanwhile, the different of ability improvement of hand on both categories showed there is a significant different (value $p=0,007$, which is $p=<0,005$ ). The conclusion of this result that Virtual reality Exercise with Sensor Leap Motion Controller better than conventional exercise to enhancement of functional hand for Stroke patience.
\end{abstract}

Keywords: Stroke, ability of hand functional, Exercise of Virtual reality, Conventional exercise, Wolf Motor Function Test. 


\section{PENDAHULUAN}

Kesibukan yang luar biasa terutama di kota besar membuat manusia terkadang lalai dalam menjaga kesehatan tubuhnya. Pola makan tidak teratur, jam kerja berlebihan, kurang olahraga, stress serta mengkonsumsi makanan cepat saji sudah menjadi kebiasaan lazim yang berpotensi menimbulkan gangguan kesehatan terutama serangan stroke. Stroke menjadi salah satu penyakit yang ditakuti karena menjadi penyumbang angka kematian yang cukup besar dengan perkembangan kematian akibat stroke mencapai $85,5 \%$ di dunia, dengan dua per tiga stroke sekarang terjadi di negara-negara berkembang. ${ }^{1}$

Di Indonesia, stroke menempati urutan pertama sebagai penyebab kematian di Rumah Sakit. Sekitar 500.000 penduduk Negara Indonesia setiap tahunnya terkena serangan stroke, $25 \%$ diantaranya meninggal dunia dan sisanya mengalami kecacatan ringan maupun berat. Stroke atau cerebrovascular accident merupakan gangguan neurologis pada otak yang menyebabkan terjadinya defisit neurologis salah satunya adalah kelemahan ekstremitas yang menyebabkan adanya keterbatasan fungsional anggota gerak atas yaitu tangan, oleh karena tonus abnormal sehingga otot menjadi tidak stabil. Dengan demikian pasien stroke mengalami kesulitan dalam melakukan gerakan fungsional tangan yaitu dengan pola yang tidak normal dikarenakan terjadi gerakan kompensasi. ${ }^{2}$

Sebagai salah satu profesi kesehatan, fisioterapi berperan dalam penanganan peningkatan fungsi gerak manusia, seperti yang dicantumkan dalam PerMenKes RI No 80 Tahun 2013, bahwa "Fisioterapi adalah bentuk pelayanan kesehatan yang ditujukan kepada individu dan atau kelompok untuk mengembangkan, memelihara dan memulihkan gerak dan fungsi tubuh sepanjang daur kehidupan dengan menggunakan penanganan secara manual, peningkatan gerak, peralatan (fisik, elektroterapeutis dan mekanis), pelatihan fungsi, komunikasi. ${ }^{3}$

Berbagai metode, latihan, pendekatan dan tehnik dalam bidang fisioterapi telah banyak dikembangkan dalam mengatasi masalah fisik dan penurunan fungsional tangan bagi pasien penderita stroke, diantaranya adalah latihan menggunakan Virtual reality. Saat ini metode, latihan, pendekatan dan tehnik yang diberikan oleh fisioterapis yang masih umum dilakukan untuk mengatasi gangguan gerak dan fungsi ektremitas atas maupun ektremitas bawah akibat pasca stroke adalah memberikan latihan konvensional. Dimana penderita stroke akan melakukan latihan gerakan secara mandiri atau yang dibimbing langsung oleh fisioterapisnya dalam melakukan eksekusi gerakan menggenggam, memegang, meraih atau menggapai sebuah objek nyata sebagai fasilitas / alat pendukung terapi.

Latihan konvensional lebih mengutamakan stimulasi pada propioseptif / cutaneus sehingga latihan yang dilakukan lebih banyak untuk kerja rangsangan / stimulasi pada taktil dan hanya sedikit yang melibatkan kerja fungsi visual.

Sedangkan latihan Virtual reality adalah latihan yang lebih mengutamakan/ menitikberatkan pada kerja fungsi visual. Dimana fungsi visual akan bekerja secara terus menerus dari awal dimulainya latihan hingga akhir latihan karena penderita stroke harus fokus/konsentrasi penuh pada saat melakukan latihan Virtual reality.

Virtual reality (VR) adalah salah satu aplikasi dari teknologi multimedia memiliki kelebihan dalam mendeskripsikan sebuah keadaan atau sebuah obyek dimana visualisasi yang ditampilkan tidak hanya dapat dilihat dari satu sudut pandang saja namun dapat dilihat dari segala sudut, karena memiliki 3 dimensi visual sehingga pengguna dapat berinteraksi dengan suatu lingkungan yang disimulasikan oleh komputer (Virtual Environment). ${ }^{4}$ 
Leap Motion Controller adalah alat sensor perangkat keras komputer yang rnendukung gerakan tangan dan jari sebagai masukan, yang dapat disamakan fungsinya seperti mouse, namun tidak membutuhkan kontak langsung dengan tangan atau sentuhan. ${ }^{5}$

Latihan konvensional yang digunakan dalam penelitian ini berupa latihan aktif dimana latihan ini akan dilakukan oleh pasien sendiri dan didesain sedemikian rupa dengan berbagai tujuan agar anggota gerak secara anatomis dan fisiologis dapat melakukan fungsionalnya. ${ }^{6}$

Ada banyak instrumen atau alat ukur yang dapat digunakan untuk mengukur fungsional AGA diantaranya adalah tes WMFT. Menurut Derenzo dan Fritz (2010), menjelaskan bahwa WMFT adalah pengukuran berbasis laboratorium yang digunakan untuk menilai fungsi motorik AGA. ${ }^{7}$

Berdasarkan latar belakang tersebut diatas, penulis tertarik untuk mengangkat topik tersebut kedalam bentuk penelitian, yakni dengan tujuan untuk mengetahui pemberian latihan Virtual reality lebih baik daripada latihan konvensional terhadap peningkatan fungsional tangan pada pasien pasca stroke. Pada penelitian didapatkan hipotesis, pemberian latihan Virtual reality lebih baik daripada latihan konvensional terhadap peningkatan fungsional tangan pada pasien pasca stroke.

\section{METODE PENELITIAN}

\section{A. Rancangan Penelitian}

Penelitian ini menggunakan metode penelitian eksperimental (Experimental Research). Dengan rancangan penelitian membandingkan dua kelompok yang samasama mengalami kondisi stroke fasa pemulihan fisik dan masing-masing diberikan penanganan program latihan fisioterapi yang berbeda. Pada kelompok pertama diberikan latihan Virtual reality sedangkan kelompok kedua diberikan latihan Konvensional. Pengukuran atau tes dilakukan pada saat sebelum dan sesudah latihan dengan menggunakan rancangan randomized control pre - post test design.

\section{B. Tempat dan Waktu Penelitian}

Penelitian dilakukan di Poli Fisioterapi Rumah Sakit Hermina Depok. Waktu penelitian dilakukan selama 4 minggu, dimulai dari bulan Februari-Maret 2018.

\section{Populasi dan Sampel}

Populasi dari penelitian ini merupakan pasien dengan kondisi pasca stroke yang mengalami penurunan fungsional tangan di Poli Fisioterapi Rumah Sakit Hermina Depok. Besar sampel adalah 12 orang, diambil pada populasi terjangkau yang disesuaikan berdasarkan kriteria inklusi dan eksklusi.

Sampel diambil dari populasi secara acak dengan rumus Pocock untuk menentukan besaran sampel. Sampel dibagi menjadi 6 orang pada masing - masing kelompok dengan cara random alokasi menggunakan tehnik urutan ganjil - genap.

\section{Prosedur Penelitian}

Setelah subjek menandatangi inform concent, kemudian masuk pada tahap pelaksanaan. Tahap pelaksanaan: (a) Melakukan anamnesis dan pemeriksaan fisik sampel. (b) Menetapkan kelompok perlakuan berdasarkan kriteria inklusi dan eksklusi. (c) Melakukan pengukuran WMFT. (d) Kelompok perlakuan menerima pelatihan Virtual reality dan kelompok kontrol menerima pelatihan konvensionaldengan fekuensi 3 kali seminggu selama 4 minggu. (e) Melakukan pengukuran WMFT kembali.

\section{E. Analisis Data}


Analisa data dilakukan uji independent sample $t$ test untuk menguji antara pelatihan Virtual reality dan pelatihan konvensional.

\section{HASIL PENELITIAN}

\section{Deskripsi Karakteristik Penelitian \\ Table 5.1 Distribusi sampel menurut usia dan jenis kelamin}

Distribusi Karakteristik Usia dan Jenis Kelamin Subjek

\begin{tabular}{lllll}
\hline \multirow{2}{*}{ Karakteristik } & \multicolumn{1}{c}{ Kategori } & \multicolumn{3}{r}{ Frekuensi } \\
\cline { 3 - 4 } & & $\begin{array}{r}\text { Kelompok 1 } \\
(\%)\end{array}$ & $\begin{array}{r}\text { Kelompok 2 } \\
(\%)\end{array}$ & \\
\hline Jenis & Laki-laki & $4(66,67 \%)$ & $3(50 \%)$ & 0,575 \\
& Perempuan & $2(33,33 \%)$ & $3(50 \%)$ & \\
& Total & 6 & 6 & 0,818 \\
Usia (th) & $40-55$ & $3(50 \%)$ & $4(66,67 \%)$ & \\
& $56-70$ & $3(50 \%)$ & $2(33,33 \%)$ & \\
& Total & 6 & 6 & \\
\hline
\end{tabular}

Tabel 5.1 menunjukan bahwa pada kelompok perlakuan I jumlah sampel laki - laki lebih banyak daripada perempuan, sedangkan untuk kelompok perlakuan II jumlah sampel laki - laki dan perempuan berjumlah sama.

Tabel 5.2

Rerata Nilai Wolf Motor Function Test pada kelompok perlakuan I dan kelompok perlakuan II

Rerata Nilai Wolf Motor Function Test pada Kelompok Perlakuan I dan Kelompok Perlakuan II

\begin{tabular}{llll}
\hline Kelompok & Rerata Pre & Rerata Post & Rerata Selisih \\
\hline Perlakuan I & $37,50 \pm 1,871$ & $42,83 \pm 2,229$ & $5,33 \pm 1,211$ \\
Perlakuan II & $39,33 \pm 3,141$ & $42,67 \pm 3,141$ & $3,33 \pm 0,816$ \\
\hline
\end{tabular}

Tabel 5.2 Menunjukan bahwa terjadi peningkatan rerata nilai Wolf Motor Function Test (WMFT) pada kelompok perlakuan I dari
$37,50 \pm 1,871$ menjadi 42,83 $\pm 2,229$ sebesar $14,21 \%$. Sedangkan pada kelompok perlakuan II terjadi peningkatan rerata nilai Wolf Motor Function Test (WMFT) sebesar 8,47\% dari $39,33 \pm 3.141$ menjadi 42,67 $\pm 3,141$

\begin{tabular}{lclll} 
2. Uji Normalitas dan Homogenitas Data & Tabel 5.3 \\
Uji Normalitas dan Uji Homogenitas Wolf \\
\multicolumn{4}{c}{ Motor Function Test } \\
\hline \multirow{2}{*}{ Saphiro Wilk Test } & \multicolumn{2}{c}{ Levene's Test } \\
\cline { 2 - 5 } & p-value & Keterangan & p-value & Keterangan \\
\hline Pre-Test 1 & 0,961 & Normal & & \\
Post-Test 1 & 0,024 & Tidak & & \\
Selisih 1 & 0,415 & Normal & & \\
Pre-Test 2 & 0,995 & Normal & 0,226 & Homogen \\
Post-Test 2 & 0,322 & Normal & & \\
Selisih 2 & 0,091 & Normal & \\
\hline
\end{tabular}

Berdasarkan Tabel 5.3 dapat dilihat hasil pengujian normalitas pada kelompok perlakuan I Pre-Test berdistribusi normal sedangkan Post-Test didapatkan hasil data berdistribusi tidak normal, maka untuk menguji hipotesis 1 menggunakan Wilcoxon Test. Pada kelompok perlakuan II Pre-Test dan Post Test didapatkan hasil data berdistribusi normal, maka untuk menguji hipotesis 2 menggunakan Paired Sample T-Test. Pada selisih perlakuan 1 dan perlakuan 2 didapatkan hasil berdistribusi normal, maka untuk menguji hipotesis 3 menggunakan Independent Sample T-Test.

Sedangkan untuk hasil penghitungan uji homogenitas pada kelompok perlakuan I dan kelompok perlakuan II didapatkan hasil uji statistik dengan Levene's Test pada kelompok perlakuan I dan kelompok II yaitu nilai $\mathrm{p}=$ $0,226(\mathrm{p}>0,05)$ yang berarti dapat disimpulkan data tersebut homogen.

\section{Uji Beda Peningkatan Kemampuan Fungsional Tangan Kelompok I dan II}


Tabel 5.4

Uji Hipotesis

Tabel Uji Hipotesis

\begin{tabular}{ccccc}
\hline Kelompok & Rerata pre & Rerata Post & $\mathrm{p}$ & Rerata Selisih \\
\hline $\begin{array}{c}\text { Perlakuan } \\
\text { I }\end{array}$ & $37,50 \pm 1,871$ & $42,83 \pm 2,229$ & 0,027 & $5,33 \pm 1,211$ \\
$\begin{array}{c}\text { Perlakuan } \\
\text { II }\end{array}$ & $39,33 \pm 3,141$ & $42,67 \pm 3,141$ & 0,000 & $3,33 \pm 0,816$ \\
& & $\begin{array}{c}\mathrm{p} \\
\text { value }\end{array}$ & 0,007 \\
\hline
\end{tabular}

Berdasarkan tabel 5.4 diatas hasil uji hipotesis I dengan menggunakan Wilcoxon Test didapatkan nilai $\mathrm{p}=0,027$ dimana $\mathrm{p}<$ 0,05 , hal ini dapat disimpulkan bahwa latihan Virtual reality menggunakan Sensor Leap Motion Controller dapat meningkatkan kemampuan fungsional tangan pada pasien pasca stroke.

Untuk uji hipotesis II menggunakan Paired Sample T-Test didapatkan nilai $\mathrm{p}=$ 0,000 dimana $\mathrm{p}<0,05$, hal ini dapat disimpulkan bahwa latihan aktif konvensional dapat meningkatkan kemampuan fungsional tangan pada pasien stroke.

Sedangkan untuk uji hipotesis III menggunakan Independent Sample T-Test didapatkan nilai $\mathrm{p}=0,007$ dimana $\mathrm{p}<0,05$, hal ini dapat disimpulkan bahwa latihan Virtual reality menggunakan Sensor Leap Motion Controller lebih baik daripada latihan aktif konvensional terhadap peningkatan kemampuan fungsional tangan pada pasien pasca stroke.

\section{PEMBAHASAN}

Latihan Virtual reality menggunakan Sensor leap Motion Controller dapat meningkatkan kemampuan fungsional tangan pada pasien pasca stroke.
Hasil penelitian ditemukan bahwa dasar dari semua pemulihan stroke adalah neuroplastisitas. Dari konsep neuroplastisitas diketahui bahwa semakin sering melakukan suatu gerakan, semakin banyak kekuatan otak dikerahkan untuk gerakan tersebut. Semua orang paling termotivasi oleh aktivitas yang mereka sukai. Ada kecenderungan alamiah untuk memusatkan perhatian, melatih, dan melaksanakan aktivitas-aktivitas yang sangat disukai. Ketika penderita stroke melatih apa yang menjadi kegemaran mereka, maka proses pemulihan akan terasa seperti bermain. ${ }^{8}$

Teknologi Virtual reality dinilai lebih efektif karena pengalaman yang direkam oleh otak penderita akan terasa lebih nyata. Dengan pemberian tugas-tugas motorik oleh fisioterapis yang ditunjang dengan teknologi Virtual reality yang berkesinambungan dengan pola gerakan yang tepat dan berirama akan menghasilkan proses pembelajaran bagi penderita hemiparese sehingga penderita tersebut akhirnya dapat melakukan gerakan dalam hal ini khususnya tangan secara mandiri. ${ }^{9}$

\section{Latihan aktif konvensional dapat meningkatkan kemampuan fungsional tangan pada pasien pasca stroke.}

Hasil penelitian ditemukan bahwa pada latihan aktif konvensional akan terjadi proses pembelajaran dari aktifitas sistem saraf pusat dimana akan terjadi motor relearning dan plastisitas. Latihan aktif konvensional merupakan latihan dimana pasien melakukan secara aktif dan melihat apa yang dia lakukan sehingga akan mengaktifkan sistem saraf pusat yang menuju sistem saraf motorik dan juga akan memperbaiki sinergis gerakan atau sistem koordinasi. $^{9}$

Latihan motorik yang dilakukan berulang kali akan mengubah korteks somatosensorik hemisfer yang bersangkutan. Jika aktivitas 
semakin sering dilakukan berulang, maka akan terjadi remodelling sinaps yang bisa bersifat sementara ataupun menetap yang dapat membentuk long term potentiation (LTP) pada hubungan sinaps.

Latihan Virtual reality menggunakan Sensor Leap Motion Controller lebih baik dari pada latihan aktif konvensional terhadap peningkatan kemampuan fungsional tangan pasien pasca stroke.

Hasil penelitian ditemukan bahwa hasil akhir yang dapat dibuktikan dari penelitian ini adalah bahwa latihan Virtual reality menggunakan Sensor Leap Motion Controller dan latihan aktif konvensional sama-sama meningkatkan kemampuan fungsional tangan pada pasien pasca stroke. Tetapi terdapat perbedaan pengaruh diantara kedua intervensi tersebut. Pada sistem saraf pusat, visual sangat besar pengaruhnya. Dalam latihan Virtual reality menggunakan Sensor Leap Motion Controler, dapat mengaktifkan secara otomatis mekanisme saraf yang sama yang dipicu oleh pelaksanaan gerakan. Sedangkan pada latihan aktif konvensional, aktifitas fungsional memerlukan pengalaman dan pemahaman tertentu secara spesifik menurut tempat dan tugasnya, sehingga membutuhkan relearning dengan cara memberikan stimulasi taktil sebanyak mungkin pada sisi yang sakit dan mengajarkan kembali pengaturan posisi dan gerak. Latihan aktif dapat memberikan proses pembelajaran aktifitas fungsional serta menerapkan premis dasar bahwa kapasitas otak mampu untuk reorganisasi dan beradaptasi, dan dengan latihan yang terarah dapat membaik. Metode motor relearning dapat mengeliminasi gerakan yang tidak diperlukan dan meningkatkan kemampuan pengaturan postural dan gerakan. ${ }^{7}$

Virtual reality memfasilitasi fisioterapi untuk melakukan rehabilitasi pasien stroke secara interaktif, berintensitas tinggi dan repetitive dari anggota gerak atas atau angggota gerak bawah yang mengalami keterbatasan gerak fungsional dan perlu dilatih.

\section{SIMPULAN}

Dari penelitian ini dapat disimpulkan bahwa, latihan Virtual reality menggunakan Sensor Leap Motion Controller lebih baik dari pada latihan aktif konvensional terhadap peningkatan kemampuan fungsional tangan pasien pasca stroke.

\section{DAFTAR PUSTAKA}

1. Feigin V, Barker S - Collo. 2006. The Impact of Neuropsychological Deficits on Functional Stroke OutcomesNeuropsychology Review

2. Feigin V. 2005. Stroke Epidemiology in The Developing World-The Lancet

3. PMK RI No Lembar Negara 80. 2013. Tentang Penyelenggaraan Pekerjaan dan Praktik Fisioterapi

4. Mihelj M, Novak D. 2014. Interaction With a Virtual Environment - Virtual Reality Technology and Applications

5. Indonesia YS. 2007. Pengetahuan Sekilas Tentang Stroke. http://www.Yastroki.or.id/read

6. Fritz. 2010. Measurement Structure of The Wolf Motor Function Test Implications for Motor Control Theory. Neurorehabilitation and Neural Repair. 24 (9), 791-801.

7. Levin M, Seposnik G. 2011. Virtual Reality in Stroke Rehabilitation: A MetaAnalysis and Implication for Clinicians Stroke Outcome Research Canada (SORCan)

8. Adler P. 2008. The Cyber World of SelfInjures: Devient Communities, Relationships and Selves-Symbolic Interaction

9. Irfan M. 2010. Fisioterapi Bagi Insan Stroke. Yogyakarta-Graha Ilmu 